\title{
Catatan Managing Editor JPS: Pengantar Vol. 19 (3) tentang psikologi politik dan perubahan sosial
}

\author{
Muhammad Akhyar \\ Fakultas Psikologi, Universitas Pancasila, Jakarta Selatan, DKI Jakarta
}

\author{
"Dunia politik dunia bintang \\ Dunia pesta pora para binatang, asik gak \\ asik" \\ (Iwan Fals, 2004)
}

Lagu "Asik Gak Asik" lamat-lamat terdengar di kepala saya saat membaca empat artikel bertema Psikologi Politik dalam edisi kali ini. Reduksionisme sarkastik Iwan Fals tentang dunia politik dengan fokus pada tabiat aktor politik, tentu tak begitu salah. Semangat ini mirip seperti di masa-masa awal Psikologi Politik mulai berkembang di tahun 1920-an, kajian di bidang ini juga lebih berfokus pada kepribadian dan motivasi dari pemimpin dan politisi dengan pendekatan psikoanalisis (Cottam, dkk., 2016). Seiring waktu, Psikologi Politik mulai membahas fenomena psikologis ke area politik yang lebih luas, termasuk di dalamnya tentang partisipasi publik dalam politik hingga kekerasan yang didorong oleh ideologi tertentu.

Selain empat artikel tersebut, volume 19 edisi ketiga dari Jurnal Psikologi Sosial di tahun 2021 ini juga memuat tiga naskah lain dengan topik yang tak kalah menarik yaitu stereotipe terhadap orang dengan difabilitas mental, motivasi relawan, dan pengambilan keputusan pada remaja yang terlibat prostitusi.

Naskah pertama ditulis oleh Celina dan Arjadi (2021) dengan pembahasan terkait bagaimana pemberian informasi mengenai status gangguan mental dapat memengaruhi penilaian daya tarik fisik. Studi ini menarik karena partisipan eksperimen adalah mahasiswa psikologi. Temuan riset ini menunjukkan bahwa paparan informasi yang diasumsikan lebih banyak terkait kesehatan mental karena berkuliah di bidang psikologi tidak cukup menahan penurunan penilaian terkait daya tarik fisik.

Naskah kedua ditulis oleh Caesara dan Yustisia (2021). Studi ini menunjukkan bahwa need for closure memiliki peran sebagai moderator terhadap hubungan fundamentalisme agama dan toleransi politik. Temuan ini menjadi sumbangan yang berarti untuk menjawab mengapa pada riset-riset sebelumnya didapatkan hasil bahwa hubungan fundamentalisme agama dengan toleransi politik tidak terlalu kuat.

Jika naskah kedua menelisik fundamentalisme agama pada partisipan muslim, naskah ketiga yang ditulis Istiqomah (2021) menemukan bahwa totalisme Islam memediasi secara penuh hubungan antara Social Dominance Orientation dan Right Wing Authoritarianism terhadap sikap politik konservatif partisipan muslim. Dua naskah ini lahir dari kegelisahan terhadap adanya kecenderungan pada sebagian umat Islam untuk mengabaikan nilai-nilai sipil yang menopang sistem demokrasi di Indonesia.

Sementara itu, naskah keempat ditulis oleh Adinugroho (2021). Penulis melihat bahwa partisipasi politik, terutama di internet, lebih didominasi oleh pria. Padahal suara perempuan dalam kebijakan publik tidak kurang pentingnya. Studi ini menemukan bahwa perempuan dan pria memiliki motif yang berbeda dalam berpolitik melalui internet. Sementara partisipan perempuan lebih memanfaatkan nilai-nilai dasarnya dalam bentuk dukungan pasif, partisipan pria lebih berkonsentrasi pada partisipasi aktif.

Naskah kelima ditulis oleh Akhtar, Pertiwi, dan Mashuri (2021). Riset berjudul "Eksplorasi Motivasi Relawan dan Implikasinya: Sebuah Perspektif Indigenous Psychology" ini menemukan bahwa nilai pribadi seperti "panggilan hati untuk bermanfaat bagi orang lain" adalah motivasi paling banyak yang mendorong seseorang menjadi relawan. Pemahaman mengenai motivasi yang mendasari perilaku ini penting karena riset ini juga membuktikan bahwa terdapat perbedaan intensi untuk melakukan kembali perilaku kerelawanan di masa depan berdasarkan jenis motivasinya.

Naskah keenam dilakukan oleh Pranawati (2021) dengan pendekatan studi kasus pada partisipan yang terlibat prostitusi sejak sebelum berusia 18 tahun. Peneliti menemukan bahwa proses pengambilan keputusan pada remaja perempuan untuk terlibat prostitusi terdiri dari tujuh tahap, yaitu: (1) mengalami permasalahan di dalam keluarga; (2) mencari dukungan sosial dari teman; (3) terpapar kenakalan remaja; (4) kebutuhan uang; (5) terpapar dunia prostitusi; 
(6) terlibat prostitusi; dan (7) keinginan dan usaha untuk keluar dari prostitusi.

Naskah ketujuh, kembali ke Psikologi Politik, dengan judul "Kalkulasi Vote Buying-Short Form (VB-S) Dalam Pemilihan Umum" ditulis oleh Sumantri (2021). Penelitian ini bertujuan untuk mengembangkan satu alat ukur guna menerka persepsi maupun sikap partisipan terkait penerimaan praktik vote buying. Naskah ini sangat relevan untuk riset selanjutnya terkait fenomena politik uang yang masih marak, terutama menjelang pemilihan umum di Indonesia.

Melalui kesempatan ini, JPS juga menginformasikan bahwa Temu Ilmiah Nasional Ikatan Psikologi Sosial ke-10 (TEMILNAS IPS X), setelah ditunda lebih dari setahun, akhirnya akan dilakukan pada 14-16 September 2021 secara virtual meeting. Tema kegiatan ini adalah "Kontribusi Psikologi Sosial dalam Masalah Lingkungan: Proteksi, Konservasi, dan Kualitas Interaksi Sosial". Topik yang sangat relevan dengan laporan dari Intergovernmental Panel on Climate Change (2021) yang menyatakan bahwa sejak tahun 2011 suhu permukaan Bumi meningkat sebanyak 1,09 derajat Celcius yang mengakibatkan permukaan air laut naik ratarata 3,7 mm setiap tahun. Lebih jauh, JPS sebagai rekan publikasi Temu Ilmiah ini membuka pintu sebesar-besarnya kepada riset-riset yang dibawakan di kegiatan ini untuk dapat diterbitkan di JPS.

Terakhir, saya mewakili tim editor JPS berharap riset-riset yang dipublikasikan pada edisi ini bisa berdampak bagi kemalaran perkembangan ilmu di Indonesia. Merdeka!

\section{Daftar Pustaka}

Adinugroho, I. (2021). Basic human values and political participation on the internet: Different basic motives for male and female groups. 19(3), 193-205. http://doi.org/10.7454/jps.2021.22
Akhtar, H., Pertiwi, R. E., \& Mashuri, M. F. (2021). Eksplorasi motivasi relawan: Sebuah perspektif indigenous psychology. Jurnal Psikologi Sosial, 19(3). 206-216. http://doi.org/10.7454/jps.2021.23

Caesara, A. D. \& Yustisia, W. (2021). Karena faktor agama atau gaya berpikir? Peran fundamentalisme agama dan need for closure dalam memprediksi toleransi politik. Jurnal Psikologi Sosial, 19(3), 170-179. http://doi.org/10.7454/jps.2021.20

Celina, A. M. \& Arjadi, R. (2021). Stigma terhadap Orang dengan Gangguan Mental: Pengaruh informasi status gangguan mental terhadap penilaian daya tarik fisik pada mahasiswi S1 Psikologi. Jurnal Psikologi Sosial, 19(3), 158169. http://doi.org/10.7454/jps.2021.19

Cottam, M. L., Mastor, E., Preston, T. \& DietzUhler, B. (2016). Introduction to Political Psychology $3^{\text {rd }}$ Edition. Routledge

Intergovernmental Panel on Climate Change. (2021). Climate Change 2021: The Physical Science Basis. Cambridge University Press. In Press.

Istiqomah, I., Shadiqi, M. A., Takwin, B., \& Muluk, H. (2021). Efek mediasi totalisme Islam pada hubungan antara Social Dominance Orientation dan Right-Wing Authoritarianism terhadap sikap politik konservatisme Islam. Jurnal Psikologi Sosial, 19(3). 180-192. http://doi.org/10.7454/jps.2021.21

Pranawati, S. (2021). Pilihan rasional ataukah pilihan yang terikat secara sosial? Studi kasus pada remaja perempuan yang terlibat prostitusi. Jurnal Psikologi Sosial, 19(3). 217-230. http://doi.org/10.7454/jps.2021.24

Sumantri, M. A. (2021). Kalkulasi Vote BuyingShort Form (VB-S) dalam pemilihan umum. Jurnal Psikologi Sosial, 19(3). 231-240. http://doi.org/10.7454/jps.2021.25 